Article

\title{
In War Time: Dialectics of Descent, Consent, and Conflict in American Nationalism
}

\author{
Susan-Mary Grant
}

Faculty of Humanities and Social Sciences, School of History, Classics and Archaeology, Newcastle University, Newcastle NE1 7RU, UK; susan-mary.grant@ncl.ac.uk

Received: 27 August 2018; Accepted: 17 October 2018; Published: 22 October 2018

\begin{abstract}
The United States, according to sociologist Seymour Martin Lipset, was the 'first new nation'. It may be at least anticipated, therefore, that genealogy, history, and the narration of time would prove more than usually complicated in a political state united across time and space solely by a civic idealism, and a people bound together only by what president Abraham Lincoln romantically described as 'mystic chords of memory'. In order to probe the nationalist lineaments of America's particular approach to locating the nation in time and in tradition, this paper traces a genealogy of American nationalism by interrogating three specific national discourses that have been of significance to the United States since its colonial beginnings. First, the identification of America as the New Israel in the New World; the attempt to inscribe the nation into spiritual, Biblical time. Second, the racial distinctions that America deployed to sustain a civic version of ethnic genealogical determinants, and to construct a coherent narrative of national lineage that embedded its citizens in time and space. And, finally, the role that conflict played, and still plays as both a central core and historical framework for both the narration, and the collapsing of time in the United States today.
\end{abstract}

Keywords: United States; time; territory; kinship; Civil War; ethnicity; nation; lineage; race

\section{Introduction}

'Ah, time! And we, time's children! We faded in her, we drooped and dropped to earth; but life and youth were always above earth. Life was young, youth was always alive, with and beside us as we dropped away. There was yet a space when time was still ours already when it belonged to youth. When we could still see youth and kiss its smooth brow, that was our own youth returned; and it had been born out of us.'

(Mann [1939] 1990)

'Time present and time past are both perhaps present in time future and time future contained in time past.'

(Eliot 1936)

Speaking in 1820, New Hampshire politician and future Secretary of State Daniel Webster mused on the role of time in the American national narrative, the nation's unique position at the confluence of past, present, and future. Webster reminded his audience that they were 'not mere insulated beings, without relation to the past or the future. Neither the point of time, nor the spot of earth, in which we physically live, bounds our rational and intellectual enjoyments,' he assured them, because '[w]e live in the past by a knowledge of its history; and in the future by hope and anticipation.' For Webster, Americans could only benefit from what he evoked as a peculiarly proximate relationship to the past and to their ancestors, whose example he advised his listeners to contemplate, whose character he urged them to study, and whose sentiments, spirit, and suffering he encouraged them to sympathize 
with. In this way, he assured them, 'we mingle our own existence with theirs, and seem to belong to their age' (Webster [1820] 1821, pp. 5-6).

Webster's address can be read as evidence of the nineteenth century's growing fascination with America's Founding Fathers, the tendency—still evident today—to assume that the nation's founding was not simply 'unique and especial' but 'a static and completed event. It is as if all human knowledge and wisdom came together in that fifteen-year moment,' legal scholar and historian Steven Green has argued, such that 'that long-developing notions of democracy, freedom, equality, and civic virtue reached their apex between 1775 and 1790 and then ceased developing' (Green 2015, p. 132). That the founding era was, and remains of special significance for Americans, is not surprising. For many years, the scholarly debate over the validity and modernity of the nation state, included those who, pursuing a particularly purist primordialist/perennialist paradigm, argued that settler nations such as America, lacking both an ethnic substructure and a temporal trajectory of tradition, are inherently inauthentic. 'Whatever the American people are (and they may well be sui generis),' Walker Connor once proposed, 'they are not a nation in the pristine sense of the word' (Connor 1978, p. 381; Connor 2004, pp. 40-41; challenging this point see Grant 2005, pp. 157-58; Grosby 2018a, p. 14).

The United States, for some, sustains merely a flimsy fabrication of a national fabric; the multiple threads of its discrete demographic identities wind back to foreign lands and distant national determinants, and cannot readily be drawn together around either an ethnic (in a narrow genealogical sense) or civic (in a broader cultural sense) core. In this context, the American fixation on the nation's founders makes sense, but whether it follows that the nation's 'founding myth is more important than it is for most other peoples' is less certain (Green 2015, p. 16). The purported authenticity accorded a state by its citizens' ability to locate themselves genealogically and geographically, to invoke memories of their own ancestral as well as their state's past as a means of justifying its physical parameters, stabilizing its political present, and assuring its emotional as much as its economic future is a crucial component of many national narratives. And few, if any, of these are grounded by any objective ethnic, genealogical determinants.

What does set the United States apart is the inflexibility, the essentially static nature of its invented traditions, as Eric Hobsbawm and Terence Ranger have delineated the symbolic and frequently 'factitious' aspect of national identity formation, and the fixed ethnic and civic parameters within which American symbolism is located (Hobsbawm and Ranger [1983] 2003, pp. 1-2). This is the sense that Green identified, but developed largely only in respect of religion, that America's national core, once created, effectively 'ceased developing' (Green 2015, pp. 132-33). Although, over three decades after Hobsbawm and Ranger made the point, the 'process of creating ... ritual and symbolic complexes' remains somewhat understudied, approaching United States nationalism from a temporal perspective enables us to appreciate better the American imperative to prove its credentials as the 'first new nation' (Hobsbawm and Ranger [1983] 2003, p. 4; Lipset 1979). This imperative was grounded in conflict, protected by the political and cultural parameters of the nineteenth-century state, and productive both of symbolic stagnation and racial division across the timeline of the nation's emergence from its colonial past to the present day. The nation of the future, in short, remains largely trapped in its past.

A broader genealogical approach is of particular value in examining this aspect of American nationalism, both in countering any residual belief that the United States is somehow lacking in respect of its national credentials, and in facilitating our understanding of the role that time plays in coordinating those credentials. Genealogy, in its focus on what political theorist Martin Saar sums up as 'a web of relations between realms so far understood to be worlds apart, as culture and violence, morality and aggression, religion and self-negation' may provide a clearer road map into a nation constructed on contradictions: be these slavery and freedom, North \& South, Cavalier and Yankee, Indian and African American, revolution and Civil War, immigrant inclusion and an aggressive 'America First' exclusionary ethos, racial equality and white nationalism, or the political separation of church and state and an energetic, equally exclusive evangelical Protestant perspective (Saar 2008, p. 307; Taylor [1957] 1979; Grant 2000). 
Further, genealogy's emphasis on the contingent in respect of 'cherished ideas and entrenched practices' in both historical and national narratives, together with its roots in nineteenth-century historicism, in which principles including 'liberty, reason, nation, and statehood' dominated the debate, renders it almost custom-built as a tool with which to probe a nation formed, to a large extent, over the course of that century (Bevir 2008, pp. 264-66). Genealogy may be, as Saar has argued, 'a hybrid discourse,' but in its emphasis on 'the histories of values, practices and institutions that relate to subjectivities and self-formation,' its ability 'to relate the historical data to an account of forces and powers,' and its awareness of an historical text's audience, it can afford us a stronger purchase on the loci of nationalism, and its transmission through time in the United States (Saar 2008, p. 312).

Pursuing the genealogical approach largely as Saar has defined it, this paper interrogates three specific nationalist discourses that have been of significance to the United States since its colonial beginnings. First, the identification of America as the New Israel in the New World; the attempt to inscribe the nation into spiritual, Biblical time. Second, the national narrative that nineteenth-century Americans constructed to sustain a civic version of ethnic genealogical determinants and national lineage that embedded its citizens in time and space. Third, the role that conflict played, and still plays as both central core and historical framework for both the narration and the collapsing of time in the United States today. This approach acknowledges the impact that the postmodern 'temporal turn' has had on our understanding of both social and historical time, and the emphasis on 'indeterminacy, incompleteness and fragmentation' that results. Time, it accepts, is 'a condition of thought' that determines 'the way we see ourselves, our families, our society and our fellow human beings' (Adam 1995, pp. 23, 149, 155; Hunt 2008, p. 4).

In asserting independence, America's revolutionary leaders made a temporal case in regards to 'Life, Liberty, and the pursuit of Happiness' (Declaration of Independence, 1776) but their patriotic rhetoric was already compromised by its internal contradictions in respect of time. Many years ago now, historian Major Wilson noted that in Europe, the alternative understandings of positive progress, self-knowledge, and national definition as proposed by, first, Descartes, who argued for the act of creation as singular and immediate and, second, Pascal, who argued for a more gradual development over time, were regarded as radical and conservative, respectively. In America, by contrast, 'the result was a paradoxical blend' productive of the kind of 'timeless and universal idea' that Hans Kohn and others have located in America; the 'ideological assumption,' in political scientist Michael Shapiro's words, 'that the national culture is a consequence of a unique mission that must be continually sacrilized by a romanticization of the past' (Wilson 1974, pp. 184-85; Kohn [1944] 1945, p. 289; Kohn [1957] 1961, p. 25; Lipset 1979, p. 18; Ravitch 1990, p. 3; Shapiro 2004, p. 63).

This paper responds to, but also pushes back against that argument, along with the expectations concerning what was once confidently but now rather more cynically termed American exceptionalism, that it gives rise to (Kammen 1997, p. x). Over the last few years, scholars have paid increasing attention to what has been termed the 'new American exceptionalism.' Specifically, they have explored the idea that the modern nation has experienced two main forms of cultural and political recalibration: first, in the context of the political and economic changes begun in the late 1960s and arguably epitomized by the rise of neo-conservatism in the following decades; and second, in the context of the era of constant conflict that the George W. Bush-defined 'War on Terror' inaugurated, following the 2001 attack on the Twin Towers of the World Trade Center in New York (Pease 2009; Rodgers 2012; Dudziak 2012). A longer-term temporal perspective, however, suggests that there is little really that is new about this new exceptionalism, and that perceived political and social fractures followed already existing fault lines in the national fabric (Rodgers 2012; Dudziak 2012, p. 118). By looking through the lens of time, indeed, it becomes evident that the past, present, and future in America have always existed in what can best be described as a state-sponsored stasis, in every sense of that term: stagnation, equilibrium, and civil conflict (Lange 2017; Lintott 2015, pp. 90-91; Orwin 1988, pp. 832-35). 


\section{Biblical Time: Securing Spiritual Space}

For America's sixteenth president, neither the longevity nor the authenticity of the United States were assured or certain. Long before he led the nation through its destructive mid-nineteenth century civil conflict, Abraham Lincoln voiced his concerns for his nation's likely survival as a distinct nation. 'If destruction be our lot,' he argued, 'we must ourselves be its author and finisher. As a nation of freemen, we must live through all time, or die by suicide' (Lincoln 1838, p. 109). Time. That was the cornerstone of Lincoln's understanding of his nation's case for existence; but not time past, time future. The United States existed, for him, in a secular political space, dominated by a New World national time distinct both in degree and in its democratic imperative from the dynastic time that still determined and delineated the balance of power in much of Europe. What Lincoln was invoking in 1838, therefore, was an already exceptional and a potentially eternal nation, although not, at that point, 'a nation of freemen' in any broad sense. Further, when he spoke, assuming one dates from the official termination of the revolutionary war in 1783 rather than the Declaration of Independence in 1776, the American state was only fifty-five years old.

The lack of a long history was no barrier to the development of American nationalism, however; quite the contrary. For American patriots generally, historian David Waldstreicher has argued, 'the more unprecedented everything appeared, the better,' and they strove to retain that sense of newness in every annual celebration of the nation's founding not by looking to the past but 'by always celebrating the future' (Waldstreicher 1997, p. 43). One early study of the nation's first century, Charles Bancroft's The Footprints of Time, similarly, argued for the birth of the United States as nothing less than the inauguration of a 'New Series of Ages-an epoch of popular freedom.' The 'inconceivably magnificent and influential future' for America that Bancroft envisaged would, in his view, have global resonance (Bancroft 1881, pp. 8, 11).

Bancroft's was an overt attempt not so much to write the American nation into time, as to pull time into the American national narrative. In this respect, he was following the footprints of a tradition-already evident as early as the sixteenth century-that posited the New World in near-prophetic terms, as the continuance, possibly the culmination, of Western imperial expansion (Grant 2018, p. 302; Carter [1987] 1988, p. xvi). A decade after the Declaration of Independence, New England minister Joel Barlow lauded the fact that, in his view, it was ' $[\mathrm{t}] \mathrm{o}$ the glory of the present age and the admiration of the future' that America's 'severance from the British empire was conducted upon principles as noble as they were new, and unprecedented in the history of human actions ... The present,' he asserted, 'is an age of philosophy; and America, the empire of reason. Here, neither the pageantry of court nor the glooms of superstition have dazzled or beclouded the mind. Our duty,' he averred, 'calls us to act worthy of the age and the country which gave us birth' (Barlow 1787, pp. 8, 19). Barlow, of course, was already playing with what nineteenth-century author Herman Melville later described as the 'chronometricals and horologicals' here, since it was the former colonists who had given birth to a new country, not vice versa (Melville and Forsythe 1852, pp. 371-79; Miller 1953, p. 574; Thorson 1961; Bercovitch 1978, pp. 28-30).

And as Barlow made clear, in this new nation, born out of time's natural order, the imperial impulse had been replaced by an ideological imperative. Scholars such as Kohn, who described America as 'the embodiment of an idea,' or historian Richard Hofstadter, who concluded that the nation's fate was 'not to have ideologies but to be one' have generally echoed this eighteenth-century assertion (Kohn [1944] 1945, p. 289; Kohn [1957] 1961, p. 25; Lipset 1979, p. 18; Ravitch 1990, p. 3). And as has long been recognized, this ideological imperative had its roots in liturgy rather than lineage. In the absence of a 'lost age of great ancestors' in their spiritual and spatial narrative, the colonists were nevertheless able to posit what Michel Foucault described as 'the imminence of new times and a millenary revenge' in the form of 'the coming of a new kingdom' in the New World. (Foucault 2003, p. 56). They sought, in effect, to create the kind of world that Melville described as 'the least affected by all terrestrial jarrings,' one that operated only according to 'Heaven's time' (Melville and Forsythe 1852, p. 372). This in itself was not unusual, nor a specifically American colonial phenomenon. As historian 
John Gillis reminds us, prior to the nineteenth century, it was 'God's, not man's, time that Europeans and Americans lived by.' They inhabited a world governed by a 'temporal deity' who expected 'that believers suspend all other time in obedience to his' (Gillis 1997, p. 44).

The Puritans, however, took this a stage further in their assumption that the New World was to be the New Jerusalem, in historian Michael Kammen's words, 'a site specifically favored by God-perhaps the very place that he had chosen to initiate the millennial Kingdom of Christ.' This carried along with it the hope, perhaps even the expectation, that God's new chosen people had 'escaped from the terror of historical change to live in timeless harmony with nature' (Kammen 1997, p. 175; Noble 1968, p. ix; Smith 2003, p. 49; Smith 2005, p. 101; Wilson 1974, p. 7). And although neither a specifically American colonial nor Puritan trope, the idea of the New Jerusalem certainly allowed future Americans, as historian Paul Boyer has stressed, to define 'their place in prophecy' by positing that 'Old Testament Israel was the type of America, America the antitype of Israel. This typological hermeneutic,' he observed, 'pervades the sermons of the revolutionary and early national periods' (Boyer 1992, p. 74). One New England minister summed it up in his 1799 Thanksgiving sermon when he proposed that the people of the United States come nearer to a parallel with Ancient Israel than any other nation upon the globe. Hence,' he continued, 'OUR AMERICAN ISRAEL is a term frequently used; and common consent allows it apt and proper' (Abbot 1799, p. 6; Kohn [1944] 1945, pp. 279, 665; Bercovitch 1978, pp. 77-80; Green 2015, pp. 16-17).

The post-revolutionary iteration of this particular narrative, however, had long since sheared off from its colonial beginnings when neither spiritual certainties nor national mission defined the parameters of the pulpit, although the pulpit itself most definitely defined the parameters of the Puritan world. The power of the seventeenth-century pulpit was such that it has been compared to the late-twentieth-century 'information revolution' in terms of both its reach and its significance across colonial New England. 'Seldom, if ever before,' historian Harry Stout observed-writing, of course, several decades before Americans were introduced to a daily diet of Donald Trump tweets-'did so many people hear the same message of purpose and direction over so long a period of time as did the New England "Puritans".' Over five million sermons were preached to a population just over a fifth of that total, he calculated, with the result that the 'average weekly churchgoer in New England... listened to something like seven thousand sermons in a lifetime, totaling somewhere around fifteen thousand hours of concentrated listening' (Stout 1986, pp. 3-4).

But the message of many of these sermons, grounded though it was in the concept of covenant as conveyed in Jeremiah 50:5 ('Come, and let us join ourselves to the LORD in a perpetual covenant that shall never be forgotten') was neither complacent nor, at times, confident about the consistency of that covenant. And here, too, temporal concerns may modify our representation of the Puritan's 'Great Migration', specifically the confidence with which it was undertaken. 'On closer inspection', historian David Brion Davis has observed, 'voluntary migrations have seldom been free from pain, nostalgia, and regret.' Further, in psychological terms, the experience of migration, echoing as this does 'the stages of an individual life from the departure from a natal family to aging, death, and the succession of generations' often leaves the migrant feeling 'dispossessed of place and society' (DavIs 2007, p. 126). Establishing a clear connection with the Israel of the Old Testament, therefore, was as much as an attempt to secure individual as well as spiritual space, to locate a single, displaced life within a more familiar time-frame associated with the place that had been left behind.

By inscribing the Puritan mission into Biblical time, the Puritans provided the future nation with a providential narrative that was less millenarian, and less concerned with the end of days than would be the case following the American Revolution (Stout 1986, p. 8). This New World narrative was, however, divided: Janus-faced, it looked both back to a spiritual, timeless past (Israel), and forward to a secular, temporal future (New England). It was complicated in this respect by the tendency, evident from the nineteenth-century onwards, to conflate, and thereby confuse, the separatist 'Pilgrims' with the non-separatist 'Puritans' in what had, by that point, become a national time-line dating neither from Columbus' arrival in the 'New World', nor from the foundation of Jamestown, Virginia in 1607 or 
that of Plymouth Plantation just over a decade later, but from one particular lay sermon preached by Puritan leader John Winthrop in 1630. Winthrop's lay sermon invoked the idea of a sacred covenant, specifically the risks attendant on breaking the same. He advised his congregation that:

"Wee shall finde that the God of Israell is among us, when ten of us shall be able to resist a thousand of our enemies; when hee shall make us a prayse and glory that men shall say of succeeding plantations, 'the Lord make it like that of New England.' For wee must consider that wee shall be as a citty upon a hill. The eies of all people are uppon us. Soe that if wee shall deale falsely with our God in this worke wee haue undertaken, and soe cause him to withdrawe his present help from us, wee shall be made a story and a by-word through the world (Winthrop 1630, p. 47)."

As the above extract makes clear, Winthrop's reference to Matthew 5:14 ('Ye are the light of the world. A city that is set on a hill cannot be hid') was not, as it later was and frequently still is interpreted, an assurance to his congregation that they were a chosen people, and New England a beacon for the world to marvel at. It was a warning that they, as a chosen people, were under constant, and visible scrutiny; a reminder that the 'timeless harmony with nature' they aspired to was not, in its nature, necessarily timeless (Noble 1968, p. ix).

In her analysis of religious writings, Meredith Neuman draws our attention to the ways in which this played out in her discussion of perhaps the most notable Pilgrim Father, William Bradford. Bradford recorded the gradual but inevitable disintegration of the original Plymouth community over time as 'those that had lived so long together in Christian and comfortable fellowship' were forced, for reasons of space and economic survival, to 'part and suffer many divisions.' Elsewhere, he mused on how 'sweet and precious were the fruits that flowed' from the 'scared bond' that pertained between the first colonists, and on the 'ruin' likely to result 'when this fidelity decayed.' Most revealing of all, the conclusion of his history of the colony, Of Plymouth Plantation, consisted in several blank, but future-dated pages. 'The aporia suggested by the empty headers, set to receive the revelation of worldly time in the godly colony,' Neuman proposes, 'disciplines any possibility of saintly certainty' (Bradford 1953, p. 253; Neuman 2013, pp. 165-66). Bradford was not alone in his fears. Peter Bulkeley, moderator of the Cambridge Synod of 1637, warned his following that 'the Lord looks for more from thee, then from other people ... Take heed lest... God remove thy Candlesticke out of the midst of thee; lest being now as a Citie upon an hill, which many seek unto, thou be left like a Beacon upon the top of a mountaine, desolate and forsaken' (Stout 1986, p. 26; on this point see also Bercovitch 1978, pp. 3-5).

Uncertainty about the spiritual and spatial security of the 'city on a hill', for individuals like Bradford and Bulkeley, was located in the awareness of time's entropic tendencies. 'Within the first decade of settlement', Sacvan Bercovitch noted, 'the clergy were already thundering denunciations of a backsliding people,' but a chosen people with a sacred mission. This, Bercovitch stressed in his famous analysis of the 'American Jeremiad', was what distinguished the sermon's New World variant from its Old World iteration: the latter related 'to the city of man rather than the city of God,' and 'held out the prospect of temporal, worldly success.' The American version, by contrast, fused 'secular and scared history' in an effort to direct the colonists 'individually toward salvation, and collectively toward the American city of God' (Bercovitch 1978, pp. 6, 9; Stout 1986, p. 8). Whether this particular religious road-map actually mapped out the future direction of the United States is less certain, for two main reasons. First, as Bercovitch and others stressed, there was an inherent ambiguity contained in its coordinates. It located the New World in both the past and the future; in historical time, looking back to Israel, and in future time, as a prophetic indicator of salvation. Second, its spatial determinants, fixed as these were in the 'holy commonwealth' of New England, did not automatically extend the providential mission statement across the colonies as a whole (Bercovitch 1978, p. 15; Stout 1986, p. 9).

The eventual national expansion of the covenantal contract was, it is generally argued, achieved through the diaspora of Puritan discourse across both time and space in the years leading up to and following the Revolution. Cast adrift from its colonial, New England moorings by a combination of demographic growth, geographical expansion and, ultimately, the Revolution, the Puritan prophetic 
tradition is generally accepted by scholars as having formed the pattern, or template for the future national identity of what became the United States (Green 2015, p. 63). Echoes of the New England Jeremiad can certainly be heard, sometimes faintly, at other times more clearly, across the American cultural and political landscape: from the ideology of the revolutionary patriots through the Federalist papers and the emergence of a two-party political system, in Thanksgiving Day celebrations, in Fast Days and days of national humiliation sermons, in early history books, and in Fourth of July addresses (Bercovitch 1978, pp. 29, 141; Callahan 2006). At the same time, the further the nation moved in time away from its colonial origins, and in the context of demographic diversification and geographic growth, the spiritual became spatial; sacred time began to move into secular, national space.

To understand this shift, David Cheal's concept of 'temporal convoys' comprising 'individuals who share a common sense of time' is especially valuable. Without doubt, the Puritan colonists constituted just such a 'temporal convoy' in respect of the organizing principles of church and community, faith and fellowship that structured their lives and mediated their deaths (Gillis 1997, pp. 43-44). Increasingly, however, after 1776, the Revolution, the war for independence that secured the American state, replaced religion as the dominant, public binding force, ensuring the structural and spiritual integrity of that state. This is not to argue for a straightforward shift from the sacred to the secular, but rather the conjoining of 'scared and secular power', and the emergence, over time, of 'a political theology and a sacralized nation' (Callahan 2006, pp. 401-2). Indeed, the Revolution itself was located within a Biblical narrative of deliverance, as the throwing off of the shackles of slavery imposed upon the colonists by Great Britain. 'Patriot preachers', as historian John Coffey reminds us, also 'politicized the New Testament's language of liberty and its concept of redemption' (Coffey 2013, pp. 66, 73). In time, however, the Revolution as a military event, rather than the religious rhetoric behind it, became the locus of national sentiment.

After 1776, the 'temporal convoy' of what became the United States was increasingly directed not by covenant, but by conflict, and increasingly defined not by God, but by man; or, rather, by individual men, the 'Founding Fathers', whose lives became the new, national exemplars, and whose moral compass pointed the way to the national future. This was, Green has argued, part of 'a consciously created myth constructed by the second generation of Americans in their quest to forge a national identity' (Green 2015, p. 199). And certainly, by the nineteenth century, the script America followed was only partly to be found in scripture. Increasingly, it was the official documents, starting with the Declaration of Independence itself, closely followed by the Constitution, along with national histories and the census that underpinned the 'narrative performance' of the nation and imposed coherence on an increasingly diverse population. The census, in particular, swiftly became symbolic of 'the exceptional destiny of the nation,' a destiny now firmly grounded in its 'demographic vitality' and located neither in time nor territory, but in supposedly timeless principles expressed in secular, not spiritual print (Shapiro 2004, p. 49; Schor 2017, p. 2; Green 2015, p. 157).

There was, however, a fatal flaw that compromised both the original covenant and the nation constructed around it. The very concept of a 'Chosen People' is an exclusionary one, designed to demarcate the elect from the exile and, in time, the nation from outsiders. Further, although much has been made of the significance of the Biblical 'Exodus' in relation to American national identity, its applicability across a racialized and frequently divisive landscape that stretched far beyond New England, the focus on a self-selected 'Chosen People' necessarily ignores the indigenous inhabitants of the designated sacred landscape that the elect impose themselves upon (Gorski 2017, pp. 31-32; Gaer and Siegel 1964, p. 161; DavIs 2007, pp. 126, 128; Coffey 2013).

The religious overlay that the Puritan migration accorded the process of settlement in the case of the United States should not obscure the fact that the spatial usurpation of one people by another is rather more common than otherwise in human history, and not an endeavor that we can safely relegate to the past. The idea of deliverance can, after all, also be deployed as justification for oppression; the concept of covenant can serve as a tool of conquest. For some scholars, this is the crucial point. Donald Pease, for one, has deployed Richard Van Alstyne's concept of the United States 
as an 'imperium', and proposes that colonial imperialism was largely 'a cultural project involved in naming, classifying, textualizing, appropriating, exterminating, demarcating, and governing a new regime' (Pease 1993, p. 22) Arguably, appropriation and extermination, not necessarily but usually in that order, were the crucial components in America's colonial case. Both individual Puritans and, further south, the Virginia Company, at least paid lip service, sometimes much more than that, to the cultural assimilation and religious conversion of native peoples, but it was the land, not the bodies and far less the souls of its original inhabitants, that exercised most white settlers.

\section{National Time: Constructing Civic Space}

The initial colonial, and subsequent nineteenth-century justifications proposed for the acquisition of native land only make sense when viewed through a temporal lens. White settlers deliberately deployed a historical narrative through which they denied history to, and effectively appropriated the past of the aboriginal inhabitants of the land. Their arguments depended on that land being viewed, or at least described, as being in 'a state of nature,' a wilderness, 'a vast and emptie Chaos,' a blank page awaiting inscription by the incoming peoples (Everett 1855, p. 32; Winslow [1622] 1865, p. 150; Carter [1987] 1988, p. 321; Morgan 1988, p. 251). In this respect, too, the temporal convoy concept offers a clearer route into the construction of American nationalism than does Benedict Anderson's deployment of 'homogeneous, empty time' as the temporal pattern for the modern nation. The former conveys a stronger sense of disparate temporalities clashing, rather than a single, national unit cohering around a coherent, civic temporal core, an 'imagined community' structured around a temporal 'simultaneity' (Anderson 1991, p. 24). Whilst the 'homogeneity of time' incorporates 'the potential for recurring revision' of the national narrative, in America's case such a revision has not yet occurred (Hunt 2008, p. 28). Thus, whereas the nation's 'manifold temporal cultures' could, in theory, 'be assembled into a variety of different pictures', and alternative 'accounts of American nationhood,' in practice, the civic space remained as it had been initially envisaged: racially and culturally exclusive (Allen 2008, pp. 3-4, 6).

Instead, the European counter-factual description of what was in reality a vibrant landscape that was more than capable of sustaining life, revealed a clash of temporal construction when the settlers, rooted in the abstract and essentially linear constructions of 'Western time,' found themselves confronted by the more 'ceremonial,' cyclical temporal rhythms of native culture. Irish migrant James Adair, who arrived in the colonies on the eve of revolution was surprised to discover that the natives 'have no name for a year' but regarded time as a continuum (Adair 1775, p. 74; Adam 1995, pp. 31-32; Allen 1992, p. 150; Montaigne 2004, p. 352; Givens 2007, p. 30; Flaherty 1999, p. 144; Bíró-Nagy 2009). In essence, the Western construct of time, consisting as it does in 'sequences of events "strung up" on a line, which extends from the past into the future', informed and justified, to themselves at least, the approach that white settlers took both toward the native peoples and the history of the nation (Adam 1995, p. 32; Evans 2013, p. 64).

In this respect, Deborah Bird Rose's discussion of the colonial encounter in an Australian context is both valuable and capable of application to the American experience, largely because of the ways in which it attends to the tempo of the encounter. Rose notes that there is an obvious American evocation of this encounter in the title, and indeed the plot, of James Fenimore Cooper's famous historical novel The Last of the Mohicans (1826). On the colonizing frontier, Rose argues, the 'White man knows that he belongs to the future, and that the Aboriginal man belongs to the past. The dynamic between them,' she proposes, is therefore 'an act of conferring.' It is an encounter with a generational, linear direction, she concludes: 'the ancient autochthon passes away and the settler takes his place as the new (and superior) indigene' (Rose 2004, p. 117; see also Krichauff 2017). The dictates and traditions of Western time, in other words, predisposed the settlers to assume that a chronological pattern or template applied, against which they measured, and found wanting, the more traditional temporal pace of native society. This was not a naïve conclusion; clearly it was both opportunistic and racialized to a great extent. Its influences are perhaps most evident in New England doctor and writer Oliver 
Wendell Holmes, Sr.'s description of the native as little more than a 'red crayon sketch' of 'rudimental manhood,' destined to be erased in the fullness of time by a more advanced society (Brainerd and Brainerd 1901, p. 298).

What Holmes was exhibiting here was an example of what historian Graeme Davison, also writing in the context of Australia, termed 'divided time', a before and after temporal justification for the spatial, social and cultural removal of America's native nations and their replacement by the white, settler society (Davison 1993, p. 8). In the process, Holmes was acknowledging the presence of the native as 'other', in Paul Carter's phrase, 'a prehistory that history had to fight' (Carter [1987] 1988, p. 321). It may be thus assumed that, in all significant respects, America's aboriginal peoples lost that fight. Purely in temporal terms, this may be a mistake. There are grounds for questioning the extent to which the settler society succeeded in imposing its particular, Western temporal template upon the land and the nation that ultimately emerged there, for two main reasons. First, the inevitable focus on the Revolution as the founding act of the United States planted that event at the center of the national community in ways similar to the processes of native, cyclical, ceremonial time and 'sense of time and history' within traditional culture. Second, and evincing similar parallels with the native sense of time as a 'corridor' through which past and present interact both temporally and spatially, has been the American engagement with the history of both the Revolution of the eighteenth century, and the Civil War of the nineteenth century, in the process of creating a racialized, exclusionary civic space (Bíró-Nagy 2009).

It is entirely unsurprising that a Fourth of July oration, delivered only a decade after the Declaration of Independence by John Brooks, a revolutionary war veteran, should laud the 'national spirit' that the American patriots 'discovered during the war' itself.' More surprising is how brief Brooks believed this revolutionary, revelatory moment, how fragile the 'national spirit' it prompted, was when removed from the arena of conflict. 'A review of the temper and manners of the people,' he asserted, reveals that the military struggle 'to greatness, however hazardous, is more pleasing to the great mass of mankind, than the practice of those virtues, which can alone secure respectability in the calm season of peace.' Ever since the Revolution, in Brooks' opinion, and absent a 'common enemy ... the states have been receding from each other, and from their common center, till the power of political attraction has become almost imperceptible.' The question for him, as for many of his former comrades, was how to extend the nationalizing power of what he now believed had been but 'a transient glow of patriotism' (Brooks 1787, p. 2). The answer that many of the elite, at least, arrived at, becomes evident if one jumps forward several decades to another Fourth of July oration, this time delivered in Dorchester, Massachusetts by noted New England statesman and orator, Edward Everett. In this case, the clue is in the title: Dorchester in 1630, 1776, and 1855 (Everett 1855).

A close reading of Everett's address supports the assertion that, in a nationalist context, the past 'has no status apart from its relation to the present' (Adam 1995, p. 79). The occasion, the celebration of independence, might be expected to call forth a meditation on America's history, not least because, as Everett acknowledged, 'the salutary teaching of national events' was 'instructive to the young, renovating to the aged, and morally profitable to the nation.' However, Everett's oration was especially revealing in terms of his treatment of the role that time played in the history that he was summarizing. In the history of Dorchester, he observed, one could trace the 'three great divisions of political philosophy ... The foundation of a State ... a new people called into the family of nations ... the political life of a community' and, finally, the Revolution itself. He slipped in a sliver of temporal one-upmanship when he reminded the citizens of Dorchester that their ancestors had made landfall some ten days before the Arabella, the famous ship that conveyed John Winthrop to the colonies, did so. Longevity in the land, a form of genealogical memory, reinforced what, throughout his oration, Everett defined as 'authentic history', one that transferred national authenticity to his audience through lineage (Everett 1855, pp. 2, 10, 27; Grosby 2018b, p. 10).

Further, and paralleling the process that Rose described in respect of the settler/aboriginal exchange, Everett located this history in a global context. He identified the United States not just as a 
new but in some senses as the replacement nation, emerging triumphant from the 'ruins' of Europe. Contrasting Dorchester, Massachusetts with the English town it had been named for, he proposed that for the latter 'its most honored memorial in after times will be that it gave origin to this its American namesake' (Everett 1855, p. 23). This became something of a Fourth of July trope. Some two decades later, on the occasion of the nation's centennial, lawyer, statesman and descendant of John Winthrop, Robert C. Winthrop, who could trace his own lineage clearly back to the era and the individuals Everett was discussing in 1855, described Independence Hall in Philadelphia as the 'Runnymede' of the American nation; locating Magna Carta (1215) with all it associations of liberty in an English context, as destined to be superseded by the new nation across the Atlantic (Winthrop 1876, p. 2).

Even allowing for the hyperbole of an oratorical occasion intended to be as entertaining as it was educational, Everett and Winthrop's respective images of an American political phoenix rising from the ashes of Europe, a new nation forging its path clear from 'the wanderings of nations in the dark ages of the past' was striking (Everett 1855, p. 75). They not only posited the United States as the culmination of Enlightenment ideals-a typical theme of the era-but as a clear rupture in the conceptual space-time continuum stretching from the Old World to the New. Theirs was, in essence, both response to and reaction against history 'with its themes of development and of suspension, of crisis and cycle'; it was an attempt to circumvent what Foucault summed up as the 'menacing glaciation of the world' (Foucault and Miskowiec 1986, p. 22). Both men echoed themes that had already been widely disseminated in historian George Bancroft's famous History of the United States (Bancroft 1834). 'The confidence of the young republic,' commented Michael Kraus on the centennial anniversary of this work, 'never spoke with greater assurance' than in Bancroft's history (Kraus 1934, p. 672). It was a confidence grounded in what Bancroft described as the new nation's 'principles of liberty, uniting all interests by the operation of equal laws.' Through these, Bancroft asserted, America 'neutralizes the influence of foreign principles, and fearlessly opens an asylum to the virtuous, the unfortunate, and the oppressed of every nation' (Bancroft 1834, p. 3).

In keeping with what, by the nineteenth century, had become a given, Bancroft assured his readers that, prior to the establishment of white colonial settlement 'the whole territory was an unproductive waste,' inhabited by only 'a few scattered tribes of feeble barbarians, destitute of commerce, connexion, and of morals. The axe and the ploughshare were unknown,' and the soil, 'which had been gathering fertility from the repose of centuries, was lavishing its strength in magnificent but useless vegetation' (Bancroft 1834, pp. 3-4). Everett was also similarly expansive where nature and civilization were concerned. Nature, he explained, consisted in cultivation: 'dreamy lawns, dotted here and there with picturesque cottages, hung with festoons of prairie-rose and honey-suckle.' It was 'shady walks' and 'groves carefully cleared of ... thorns and brambles,' 'babbling streams' and 'bleating flocks.' Contrasting this Edenic vision against the 'broad marshes cut up with deep, oozy creeks,' that the first colonists encountered, the absence of any 'traces of humanity' simply 'aboriginal tribes' who 'hardly went as far as the beavers' in construction terms was simply another way of confirming his audience's belief that they, and not the indigenous peoples, belonged in the land. So far from nature's nation, both Bancroft and Everett described a land overrun by time, but tamed by settlers whose control of time and its ravages was what defined them as a superior people. Thus, in this 'early American exodus through the wilderness,' both detected the 'faint image of that living tide of emigration which in all subsequent time has flowed westward from the Atlantic coast' and was now expanding westwards (Everett 1855, pp. 32-33, 36).

This 'living tide' posed a challenge, however, to Brooks', Bancroft's, and Everett's respective iterations of the passage of time and its likely impact on American nationalism and individual Americans' sense of belonging. As Everett's oration made clear, by the mid-nineteenth century, the United States certainly had a degree of what Steven Grosby has termed 'temporal depth,', but expanding westwards as it still was, it was not yet a fixed national territory 'infused with this temporal depth', far less one that exhibited a secure sense of 'territorial kinship' among its population. In the case of the United States, too, the unstable 'frontier zone' that Grosby describes was not always on a physical, geographically delineated frontier. 
The boundaries between national belonging and what Edward Said described as 'the perilous territory of not-belonging' were established from the start, and have existed at the heart of the nation ever since (Grosby 2018b, pp. 8, 9-10; Said [2000] 2001, p. 177; Wilson 1974, p. 51). The Bible Commonwealth had carried its own kinship boundaries with it to New England, but William Bradford had seen these begin to disintegrate in his lifetime. The thirteen colonies had bonded in conflict, but for John Brooks, the result, in national terms, was far from secure. In short, the further along the temporal axis America's population moved from both Bible Commonwealth and Revolution, the more unstable its national base became.

Religion remained a potent and potentially stabilizing element in the national equation, as the wave of revivals that swept the northeast in the opening decades of the nineteenth century made evident. "The images of the book of Revelation', as religious historian James Moorhead has stressed, 'were virtually ubiquitous among nineteenth-century Americans.' These evidenced both a doom-laden premillennial expectation that the end of the world was, in fact, nigh, and a more positive, postmillennial revivalist impulse that, merged with the social reform imperatives of that century, encouraged outward-focused missionary activities, as well as providing the inward-focused assurance that the United States was the 'Redeemer Nation' of prophecy (Moorhead 1984b, pp. 524, 527; Friend 2018, p. 55). Yet postmillennialism, famously summed up by Moorhead as 'the moral government of God stretched out on the frame of time,' was essentially a compromise position, located between 'an apocalyptic and an evolutionary view of time' (Moorhead 1984a, p. 61). In the mid-nineteenth century, it functioned most effectively as a support structure for an early variant of American exceptionalism, and an evangelical impulse that was largely directed at a domestic, but not necessarily a home-grown audience (Moorhead 1984b, p. 528).

Growing as it arguably did out of the uncertainty attendant upon a nation fast developing, both demographically and geographically, a nation of immigrants, postmillennialism's emphasis lay in securing the future of the Redeemer Nation, largely by inculcating its ever-expanding population into the 'Chosen People' paradigm as already established in New England over the course of the eighteenth century by, among others, notable preacher Jonathan Edwards' iteration of millennialism. Taken forward into the nineteenth-century by equally voluble ministers such as Lyman Beecher, the emphasis was on education, and what Ronald Reagan later summed up as 'informed patriotism' (Reagan 1989). In 1835, Beecher had come around to Edwards' opinion that 'the millennium would commence in America ... all the existing signs of the times,' he averred, 'lend corroboration to it,' because it was 'by the march of revolution and civil liberty that the way of the Lord is to be prepared' (Beecher 1835, p. 10).

Time was the crux of the issue for the new republic from Beecher's perspective. He made this clear enough in the opening epigraph to his argument, Isaiah 66:8 ('Shall the earth be made to bring forth in one day? or shall a nation be born at once?), and developed it throughout his famous Plea for the West (Beecher 1835). In the process, he rather exploded the more improbable elements of the Puritan Exodus narrative as men like Bancroft and Everett had constructed it. 'No people ever did, in the first generation, fell the forest, and construct the roads, and rear the dwellings and public edifices' he argued; certainly 'New England did not.' Nevertheless, he asserted, since New England was both 'compact in territory' and 'homogeneous in origin, language, manners, and doctrines,' its population could be 'coerced to unity by common perils and necessities' and, crucially, they had the luxury of time for 'their institutions to grow with their growth and strengthen with their strength.' The West did not enjoy these benefits. Its population, 'assembled from all the states of the Union, and from all the nations of Europe' lacked both homogeneity and direction. 'A nation,' Beecher warned, 'is being born in a day' (Beecher 1835, pp. 3, 10-12, 15-16, 47).

For Beecher, as for many like-minded, reform-focused spokesmen in the first half of the nineteenth century, the heterogeneity of America's population combined with the political challenges of democratic rule posed a real risk that republican 'intelligence and virtue' would 'falter and fall back into a dark minded, vicious populace, a poor, uneducated reckless mass of infuriated animalism.' 'No government,' he warned, 'is more complex and difficult of preservation than a republic ... Of all the influences' likely to destroy this form of government, he concluded, 'none is more pernicious 
than a corps of men acting systematically and perseveringly for its own ends upon a community unapprised of their doings, and undisciplined to meet and counteract them' (Beecher 1835, pp. 39, 62; Quandt 1973, p. 392; Grant 2000, pp. 118-20).

Beecher believed that this threat could be countered via the expansion of democratic ideals westward through a combination of 'schools and Sabbaths and sanctuaries' that would induct into the national creed the 'ocean floods of population rolling in' across the land (Beecher 1835, p. 38). This was the reiteration of a pattern, delineated by Bancroft, later repeated by Everett and others, whereby the outsider, the immigrant was, in theory, grounded in the national soil by the power of America's political institutions. Quantitative growth need not, Beecher was arguing, involve qualitative decline. The core covenant could be protected from the ravages of time by a continuous generational regeneration. This was a secular iteration of a process that has been described by religious historian Mircea Eliade as the 'myth of the eternal return' through which time is devalued and denied, history abolished, and time's arrow suspended within a civil space both sacred and secular and, above all, cyclical; it was 'a practicable way to keep liberty from being lost in the toils of time' (Eliade [1954] 1959, pp. 36, 81, 85; Wilson 1974, pp. 109-10).

Yet time's arrow traced a very different national trajectory for many Americans, as leading African American spokesman and former slave Frederick Douglass made clear. 'For more than two hundred years,' he asserted, African Americans had 'been identified with [America's] soil, its products, and its institutions.' He contrasted their position with that of the 'persecuted red man of the forest,' who, 'escaping, as it were, before the footsteps of the white man' had virtually vanished 'from the face of the country.' This, he averred, was not going to be the fate of African Americans; 'white and black,' he insisted, 'must fall or flourish together' in the United States (Douglass 1999a, p. 148). In this respect, Douglass, possibly more in hope than expectation, was seeking alignment with an exclusionary national creed, attempting to write African Americans into that 'special form of time in which people imagine their collective life.' His battle for inclusion and equality on behalf of African Americans can be read as a clear example of the 'multifarious and protean' nature of American national time (Allen 2008, pp. 218-19). However, the persistent and far from protean ethnic and racial conflict at its core revealed that it was rather the unchanging and exclusionary nature of the nation's imagined community, and its adherence to a religiously-inflected, white temporal trajectory that defined American civic space.

Speaking a few years later, on the occasion of the fourth of July, Douglass acknowledged the Biblical echoes that permeated American nationalism. 'This, to you, is what the Passover was to the emancipated people of God. It carries your minds back to the day, and to the act of your great deliverance.' However, it was an entirely different national narrative for America's slaves. For them, the Fourth's 'prayers and hymns ... sermons and thanksgivings ... religious parade, and solemnity' were nothing but a 'hollow mockery' (Douglass 1999b). For its elite spokesmen, politicians, and religious leaders, America was created 'in one day,' in a state of metaphorical national grace. Formed for the future, for the 'pursuit of happiness' its narrative was one of 'qualitative progress,' consistent improvement, 'as the nation moved through time up the scale of civilization' (Wilson 1974, p. 5; Friend 2018, p. 53). But not for all. And the result of this inequity was, ultimately, civil conflict.

\section{War Time: From Chronos to Kairos}

Douglass's rhetorical question, '[w]hat to the American slave, is your 4th of July?' highlighted the nationalist limitations of America's Biblical and civic space, the contradictions at the heart of its covenant. It also revealed the degree to which the nation was trapped in the logic of its own spiritual and secular lineage, fixed in a singular moment of national conception that allowed it neither to retreat nor advance; even as the nation itself expanded westwards across space. Its origin narrative remained suspended in a state of stasis because, as Wilson has argued, 'its initial perfection ruled out the possibility of qualitative improvement through time' (Wilson 1974, p. 41). From the perspective of the era, there seemed to be some flexibility in the system, as that system was defined in the Declaration 
of Independence, a document that took on near-mystical powers to effect the nation's covenantal communion. Most Americans, or would-be Americans, Abraham Lincoln, speaking in 1858, pointed out, clearly could not secure their place in the nation through lineage, by blood, but had 'a right to claim' the Declaration of Independence 'as though they were blood of the blood, and flesh of the flesh' of those who wrote it. This document, he insisted, constituted the 'electric cord' that linked the nation together (Lincoln 1858, pp. 499-500). Yet if we remember that the Declaration of Independence was, to all intents and purposes, a declaration of war, its constructive covenantal inclusivity takes on a rather more destructive and violent hue.

The outbreak of Civil War following Lincoln's election in 1860 was regarded at the time, and in many ways since, as a re-run of America's founding conflict. Those southern states that formed the Confederacy may have deployed the constitutional justification of states' rights to disguise a rather more straightforward determination to retain chattel slavery and secure white supremacy, but they aligned their actions with those of the revolutionary generation, even as they fought to dismantle the Union that their ancestors had created. For northerners, defense of that Union took precedence, but eradicating the poison of slavery that had placed the 'blessings of free government' for the free in jeopardy, and denied them altogether to the slave, swiftly became part of that defense (McPherson 1994, p. 28; Mitchell [1988] 1989, p. 1). In that respect, America's civil conflict can be located within a ritual, regenerative, temporal framework, with North and South, Union and Confederacy serving as the respective 'two halves of a clan' and the Civil War generation repeating the revolutionary pattern of the eighteenth century (Eliade [1954] 1959, p. 29).

Historical assessments of the background to the war have identified divided lineage as one of the factors that exacerbated sectional tensions in the mid-nineteenth century; specifically, the idea that northerners were 'Yankees' and southerners 'Cavaliers,' deriving from quite distinct, although largely invented historical classes and cultural narratives (Taylor [1957] 1979). Echoes of those narratives can be heard in post-war recollections of the conflict, both factual and fictional; Union doctor Silas Weir Mitchell, for example, has one of his characters recall his time in 'the Third South Carolina, when we got our quietus on the crest of Cemetery Hill. What a scene that was! I can see it now. I was twice in among your people, and twice back among my own; but how, I can no more tell than fly' (Mitchell [1884] 1895, p. 40; see also Shaler 1890).

More typically, the Civil War is understood as a temporal break, a 'great gulf' in the national narrative; a dividing line between what Civil War historian James McPherson described as an antebellum 'country still basking in the glow of the Revolution that had given it birth' and a modern nation state, between a nation grounded in a system of 'slave-labor plantation agriculture' and one dedicated to a 'system of democratic free-labor capitalism' (McPherson 1991, pp. 5-7). 'Like a clock that strikes only one hour,' historian Cheryl Wells has proposed, 'the Civil War split nineteenth-century American time into two discrete units: antebellum and postbellum,' and in the process 'complicated and temporarily altered how Americans understood and used time' (Wells 2005, p. 1). Developing this idea, Mary Dudziak has examined the ways in which war 'breaks time into pieces,' in the process constructing a before and after temporal trope that the American Civil War appears, at first glance, to exemplify (Dudziak 2012, p. 3). Her argument in respect of the ways in which 'the idea of wartime' contains within itself 'a conception of the future ... a place beyond war,' emphasizes the idea of wartime as a temporary temporal shift (Dudziak 2012, p. 22). Yet there are grounds for questioning how temporary this conflict-constructed time-shift actually was in American nationalist terms.

In this respect, Dudziak's proposition that wartime is 'not merely a regulation of the clock, it is the calibration of an era' suggests that the apparent tidiness of the temporal divisions produced by war may be misleading (Dudziak 2012, p. 14). Wartime may be the norm for, and not the deviation from national time. Arguably, what Wells describes as 'battlefield time' had, and has always been, the temporal determinant of American nationalism, whether one chooses to describe it in terms of the rosy 'glow' that the Revolutionary generation and its heirs luxuriated in, or in the disingenuous post-Civil War racial and cultural construct that was the former Confederacy's 'Lost Cause.' It is as applicable to 
the brutal Plains Wars (1862-c1890) that overlapped with, extended beyond, and consequently have become overshadowed by the Civil War, as it is to the moral and materiel might that the nation brought to bear in World War Two. It can also be traced in the damaging and divisive impact of America's involvement in Vietnam, as much as through the current and potentially timeless 'war on terror'.

The Civil War did, in some respects, attempt to reset the national clock, but it was to all intents and purposes the same clock. Rather than 'God's time' becoming 'increasingly secular in the face of battle,' the evidence suggests that an earlier iteration of Biblical time was drawn forward into the Civil War (Wells 2005, pp. 5, 64). Revolutionary war sermons had reinforced 'New England's identity as an embattled people of the Word,' and revivified the concept of 'a sacred and exclusive covenant between themselves and God' (Stout 1986, p. 7). Civil War sermons, similarly, were quick 'to portray the struggle as an Armageddon of the Republic,' the opportunity for a regeneration of American society, and its rededication to the national, millennial mission (Moorhead 1984b, p. 524; Quandt 1973, pp. 392, 394; Tuveson 1968, pp. 192-96).

For Abraham Lincoln, the Civil War was in some respects, the result of the failure of Revolutionary memory. At the start of his political career, the Revolution was, for him, the key to national cohesion, specifically 'the powerful influence' that the memory of this conflict 'had upon the passions of the people as distinguished from their judgment.' The power of the Revolution to draw the population together was located, in Lincoln's opinion, in the physical evidence provided by that conflict's survivors. Every family, he pointed out, had, 'in the form of a husband, a father, a son or a brother ... a history bearing the indubitable testimonies of its own authenticity, in the limbs mangled, in the scars of wounds received ... a history ... that could be read and understood alike by all, the wise and the ignorant, the learned and the unlearned.' Yet Lincoln recognized that 'this state of feeling must fade, is fading, has faded, with the circumstances that produced it.' The war's veterans had been living manifestations of the 'pillars of the temple of liberty; and now, that they have crumbled away, that temple must fall, unless we, their descendants, supply their places with other pillars, hewn from the solid quarry of sober reason' (Lincoln 1838, pp. 111, 114; Guelzo 1999, pp. 90-91).

When sober reason gave way to armed conflict in 1861, the Civil War took its place, for Lincoln, as the opportunity for a 'new birth of freedom,' for a people united by territory and by the collapsing of time across that territory (Lincoln 1863, p. 23). 'A nation may be said to consist of its territory, its people, and its laws,' he declared in Annual Message to Congress at the end of the first full year of the Civil War. And of the three, Lincoln determined that territory was 'the only part which is of certain durability,' because, as the Bible states, only the 'earth abideth forever.' Making the case against secession and division, Lincoln stressed how 'well adapted' the United States was 'to be the home of one national family,' and how significant in this respect were those technological developments, '[s]team, telegraphs, and intelligence' that served to bring that family together across both time and space, an argument previously made by Beecher and reiterated by others in the post-war era (Lincoln 1862, p. 527; Lincoln 1861a; Beecher 1835, p. 35; Gibbons and Cardinal 1892, p. 386; Quandt 1973, p. 394). Historian John Lothrop Motley made the case at some length in his talk to the New York Historical Society three years after the war had ended. Praising the 'ever-expanding arms' of the nation, and their ability to assimilate 'the forlorn, the adventurous, the outcast' into the nation's 'own flesh and blood,' Motley echoed not only Lincoln's 1858 speech, but his wider concerns about time, past and present, in the American national narrative (Motley 1869, p. 2; Lincoln 1858).

Motley believed that 'the preservation of memorials to [America's] brief but most important Past' was crucial, because they signaled 'the era of a new civilization,' the victory of 'grandeur, luxury, wealth [and] power' over the 'primeval night' in which 'the Mohawk and the Mohican were tomahawking and scalping each other.' Like Everett before him, Motley juxtaposed nature against national nurture to make his case that 'this favored Republic, this youngest child of civilization' pointed the way to the future and towards human progress (Motley 1869, pp. 2-3, 4-6). Lincoln, not having the benefit of hindsight and Union victory when he spoke in 1862, was more circumspect. 'The dogmas of the quiet past,' he warned his audience, 'are inadequate to the stormy present,' and he urged them to 
'disenthrall' themselves of past certainties in order to secure the national future. 'Fellow-citizens,' Lincoln famously asserted, 'we cannot escape history ... The fiery trial through which we pass, will light us down, in honor or dishonor, to the latest generation,' as the Union struggled to save 'the last best, hope of earth' (Lincoln 1862, p. 537).

Yet despite Lincoln's assurance that the Civil War, the 'struggle of today, is not altogether for today - it is for a vast future also,' Civil War time, 'battlefield time,' became the determinant of the nation's temporal parameters, not just beyond the battlefield itself, but across the land long after the guns had fallen silent (Lincoln 1861c, p. 53; Wells 2005, pp. 5-7, 33). This may not be surprising. As John Hutchinson has argued, wars have often 'offered raw material for ethnic mythomoteurs' and these narratives, imbued with a religious dimension, 'have endowed populations with a sense of meaning and a unique destiny' (Hutchinson 2018, p. 12; Hutchinson 2017, p. 169). In part, the process was also a personal one, largely identified as pertaining to the white South and to the emergence of the 'Lost Cause' after the Civil War. As Mark Twain commented some two decades after the Civil War, in 'the South, the war is what A.D. is elsewhere: they date from it' (Twain [1883] 1996, p. 201). This particular temporal dimension can be traced most clearly in later literary treatments of southern life, most notably by William Faulkner who, writing from his vantage point in Mississippi, was well-placed to assess the longevity of Civil War memory in the states of the former Confederacy and the peculiarly negative nostalgia that it inculcated. For Faulkner, the Civil War had frozen time for white southerners: the Confederate clock had stopped just before two 'on that July afternoon in 1863' before the Battle of Gettysburg (Faulkner [1948] 1996, p. 195).

It was via the fictional character of Quentin Compson in Absalom, Absalom! (the title referencing the Biblical House of David) that Faulkner offered his most extended literary meditation on the weight of lineage and the extension into the twentieth century of Civil War time. Describing his sense of the South to his Canadian roommate, Shreve, at Harvard, Quentin encounters amazement. 'What is it?' Shreve asks, 'something you live and breathe in like air? a kind of vacuum filled with wraithlike and indomitable anger and pride and glory at and in happenings that occurred and ceased fifty years ago? ... so that forevermore as long as your childrens' children produce children you won't be anything but a descendant of a long line of colonels killed in Pickett's charge at Manassas?' Quentin corrects him: 'Gettysburg,' he says. 'You can't understand it. You would have to be born there' (Faulkner and O'Donnell [1936] 1990, p. 289; Grant 2004, pp. 103-7).

Thomas Wolfe, another southern writer, was similarly exercised by the echoes of the Civil War, and his characters, on their fictional visit to Richmond in 1916, hear those echoes very clearly.

They saw the state house and heard the guns. They knew that Grant was pounding away at the gates of Richmond. They knew that Lee was digging in some twenty miles away at Petersburg. They knew that Lincoln had come down from Washington and was waiting for the news at City Point. They knew that Jubal Early was swinging in his saddle at the suburbs of Washington (Wolfe [1937] 1999, p. 183).

In Wolfe's case, the date of the fictional visit was crucial; Civil War time was being collapsed into First World War time by an author who wanted to make the point that war 'cut straight across the face of time and history, a dividing line that was clear as a wall' and that rendered 'the vision of America' that his characters 'had before the war' completely and utterly 'different from the America and the vision of America they had after the war' (Wolfe [1937] 1999, p. 186).

There is no doubt that these fictional treatments of war time had their roots in a personal and persistent reality for many Americans, north and south. Historian Bruce Catton, for example, traced the origins of his professional interest in the Civil War to his upbringing in Michigan 'amidst a regular flowerbed of Civil War veterans' and the 'war stories' that made him feel 'as if the whole affair had taken place in the next county just a few years' before.' Together with Memorial Day parades, veteran speeches, and the laying of wreaths on the graves of the fallen, what Catton described as 'the Civil War thing' pervaded the culture of the twentieth-century United States (Kammen 1997, p. 6). With the 
nation on the verge of involvement in the Second World War, southern journalist Ben Robertson, similarly, recalled his grandfather's and great uncle's stories of the Civil War, their memories of the 'Seven Days' Battle, the Wilderness. General Jackson in the valley of the Shenandoah. General Lee. The sound of the Yankees' pickaxes, digging under Petersburg. And Richmond, always Richmond.' Regretful rather than romantic in its invocation of that conflict, Robertson's memoir located the war in Biblical time, and presented secession as an act of original sin. 'We loved the United States, the Union was like the Ark of the Covenant, it was holy. Our leaving the Union still troubles us in the true Biblical manner-unto the third and fourth generations' (Ayers and Mittendorf 1997, pp. 141-47).

Abraham Lincoln had, in 1862, adopted the opposite view. Then, he had voiced his belief that the Civil War 'springs not from our permanent part; not from the land we inhabit; not from our national homestead,' but from the Civil War generation itself and its struggle to locate the nation in time. In the disagreements over which came first, the Union or the States, secessionist sentiment had found a foothold, and Lincoln's argument that the 'Union is older than any of the States' was not a given, and would not be a given until military victory took the point beyond debate (Lincoln 1861b, p. 434). Even so, and in the midst of the conflict over the validity of the nation, Lincoln was confident enough to advise the American people that the 'strife pertains to ourselves- to the passing generations of men; and it can,' he reassured them, 'without convulsion, be hushed forever with the passing of one generation' (Lincoln 1862, p. 529). Clearly this was not the case, and Civil War time spilled over into the following century and beyond, into the present day.

Not the least of the reasons for this was the revivalist, regenerative rhetoric emanating from the Union side of the conflict, an invigorated 'evangelical republicanism,' much of it structured around the termination of chattel slavery. In this rhetoric, Biblical, national, and war time became intertwined, as Americans indulged in new 'visions of a coming millennium' in order to endow 'a terrible war with transcendent purpose.' So enthusiastically did Civil War-era Americans invoke the idea that they were 'a people chosen by God to carry out his mission in the world' that northern Methodist Bishop Matthew Simpson concluded that 'God cannot to do without America' (Rable 2010, pp. 3, 88, 356). As historian George Fredrickson pointed out, Simpson's views were extreme, but not unique. The northern clergy, in the process of enthusiastically taking up a new role as 'redeemers of the republic,' largely succeeded in blurring the distinction between 'the war for the Union and the Christian mission to convert the world' (Fredrickson 1998, pp. 110, 123).

For many scholars, however, this blurring of the Word and the world was most effectively achieved by Lincoln himself, in his Second Inaugural Address. Described by Frederick Douglass as 'more like a sermon than a state paper,' the temporal inflections and religious language of Lincoln's Second Inaugural, with its invocation of God's wrath being delivered on the nation for the sin of slavery, was not simply a 'culmination' of his thoughts on 'slavery and race, the meaning of nationhood, the purpose of government, [and] the role of God in the universe; it clearly bore more than a passing resemblance to the 'Puritanical sermons of his youth' (Lincoln 1865; Tackach 2002, p. xiv, 129; Leff 1988, p. 26; on this point see also White 2002; Guelzo 1999). One could also cite the president's Proclamation of a Day of Prayer in the summer of 1864, or the Proclamation of Thanksgiving, issued in the autumn of that same year; all three evidenced what Michael Leff has identified as a shift from 'a perspective grounded in secular time to one grounded in sacred time,' the insertion of Biblical time into the conflicted civic space of the nation at war (Leff 1988, p. 29; Lincoln 1864a, p. 431; Lincoln 1864b, p. 55).

In this respect, it can be argued that Lincoln took the Civil War out of the realm of chronos, chronological time, and into that of kairos, dramatic time, as these temporal constructs have been discussed by historian Nathan Friend in the context of Edwards's 'special time of revivalist millennialism' (Friend 2018, p. 61). In the process, Lincoln advanced an ideological imperative that transformed a civil conflict into a civic covenant, and accelerated Civil War time forward into the 'vast future' that he had anticipated for the United States. The Union armies were quick to disband after 1865; indeed, it became a point of national honor how speedily the sword morphed back into the ploughshare. But for Union veteran Joshua Lawrence Chamberlain, they had become immortal, 
and would remain so, 'so long as soul shall answer soul, so long as that flag watches with its stars over fields of mighty memory, so long as in its red lines a regenerated people read the charter of its birthright, and in its field of white God's covenant with man' (Chamberlain [1915] 1994, pp. 391-92).

Again, however, as with the concept of covenant, it was the gaps in that charter, its potential loopholes that persisted into the future, and that continue to inform so much of the contemporary debate over conflict and covenant in the United States. Civil War time collapsed into the later-nineteenth-century debates over race, reform, and immigration. It underpinned the twentieth-century divisions between American internationalists and isolationists in the context of conflict. Its spiritual and secular parameters expanded globally in that most overt of temporal assertions of economic, military, and moral authority, the 'American Century' that the Second World War inaugurated. But above all, present-day Americans, especially but certainly not exclusively those in the states of the former Confederacy, are faced with daily reminders that, in many respects, Civil War time remains the temporal determinant of their world. In the increasingly hostile, at times physically confrontational debates over the Confederate flag or over the many statues to Confederate generals, the focus and often the flashpoints for racial violence, the contemporary American rhetorical frame is both racially inflected and temporally trapped in a conflict that ended over one hundred and fifty years ago.

\section{Conclusions}

Michael Shapiro has described contemporary America as existing in a state of 'cultural apartheid,' and has argued that the nation's still extant color-line serves to 'impugn the dominant temporality of the modern nation state,' and in particular 'its narrative of evolving cultural cohesion' (Shapiro 2004, p. 48). Rather than impugning the temporality of the American state, however, the persistent struggle over Civil War time reveals the dominance of the temporal over the territorial in American culture. It also highlights the persistence of both 'cosmic and communal' images of time in an American context. Although it may be assumed that, as a modern nation-state, 'images, rituals, and symbols' serve little function for a population living in a century largely devoted to the personal and the individual, in fact the United States remains somewhat of an anachronism in respect of its relationship to its own past, and especially its Civil War past (Gillis 1997, p. 43). We need to be better attuned to the significance of Civil War time in American nationalism, since, as Hutchinson stresses, wars 'tend to embed a sense of historicity (however mythic) into emergent nations when they set in chain long-lasting developments' (Hutchinson 2018, p. 18).

In this respect, Shapiro's arguments in respect of the 'temporality associated with nation building,' and in particular the need for 'a continuous management of historical narratives, as well as the territorial space', are instructive (Shapiro 2004, pp. 48-49). Management of national time in the United States is largely cyclical, and static as a result, in respect of its foundational framework. For example, when America elected its first African American president, the inauguration celebrations acknowledged the Civil War's legacy in the representation, on the Washington Mall, of images of Abraham Lincoln, and in the ceremonial use of Lincoln's Bible, the first time it had been used since 1865 (The Telegraph 13 January 2009). Under the Obama administration, the contentious issue of Civil War versus Civil Rights memorialization was addressed directly in the construction of memorials at various notable Civil War and Civil Rights sites-among them Birmingham, Alabama and Beaufort, South Carolina—and in the open recognition accorded black Civil War veterans at the annual Memorial Day wreath-laying ceremony at Arlington (Washington Post 12 January 2017; New York Times 25 May 2009).

Yet this, too, may be seen as simply part of a pattern in a land once described by a nineteenth-century visitor as one of 'unfinished monuments,' but which could itself be 'imagined as an unfinished project' (Yablon 2012, p. 154). And this, of course, was largely how many Americans did, and arguably do see their nation. It was a 'City on a Hill,' but one that the world was watching closely, indeed cynically, for any signs of deterioration in the democratic discourse. It was an experiment in modern republican government, a 'proposition,' in Lincoln's words, 'that all men are created equal.' The Civil War was thus a temporal test of whether United States, 'or any nation so conceived, and so 
dedicated, can long endure' (Lincoln 1863, p. 23). The so-called 'Trumpian Backlash' against the expansive vision of the nation's racially inclusive, republican promise as that was enunciated most crisply by Lincoln and found contemporary public expression under Barack Obama simply highlights the temporal nature of America's founding ideals as these function in a national, and nationalist context (Ravindran and Hale 2017; Hindustan Times 3 November 2018).

Issuing from his supporters and detractors alike, the rhetoric that swirls around the forty-fifth president engages with the idea of time. The President's 'Make America Great Again' (\#MAGA) slogan evokes an undefined and undated past. It is sufficiently vague as to appeal to a broad demographic whose conception of what constitutes greatness, and when it was last experienced, may not be entirely consistent, but is politically potent. Donald Trump's political, academic, and media detractors, by contrast, propose that he offers 'an insult to history,' and delve into the national past for their evidence (New York Times 21 May 2017). Comparisons with the McCarthy Era and with the political battles of the Early Republic are reinforced by contrasts with both the Obama presidency and with Franklin Delano Roosevelt's 1941 State of the Union Address (the 'Four Freedoms' speech) delivered as the nation entered World War Two and was given graphic form in Norman Rockwell's famous series of paintings depicting the world that America was fighting for (Roosevelt 1941; The Guardian 7 February 2017; Washington Post 3 July 2018; New York Times 8 March 2018). These examples are further reinforced by suitably dire warnings from past presidents regarding either what George Washington, in 1796, termed 'the insidious wiles of foreign influence,' or the internal dangers that Abraham Lincoln identified almost half a century later (Washington Post 11 August 2017; National Review 6 June 2018; The Atlantic 21 July 2015; Washington 1796).

Abstracted from its spiritual context, and relocated within this secular, historical national narrative, the core component of the covenantal construct, the 'City upon a Hill,' began to function as a temporal and political marker, cautionary and assertive alike; frequently invoked in times of crisis, it has served equally well as a rhetorical prop for a more positive message (Baritz [1964] 1980; Gorski 2017, p. 190). Sometimes it acquired additional embellishments, as in 1989, when the then outgoing President, Ronald Reagan, redesigned it and accorded it physical, earthly form as a 'shining city upon a hill ... a tall, proud city built on rocks stronger than oceans, windswept, God-blessed, and teeming with people of all kinds living in harmony and peace.' No longer a warning to a Chosen People in danger of failing to live up to their sacred covenant, the city, in Reagan's interpretation, was a symbol of national strength and mission. It stood 'strong and true on the granite ridge ... still a beacon, still a magnet for all who must have freedom, for all the pilgrims from all the lost places who are hurtling through the darkness, toward home' (Reagan 1989).

More recently, and in the context of the Obama administration, Winthrop's image of the 'City upon a Hill' has served as a warning against an age of growing American inequalities; economic, social, gender, and racial. 'It may be that in our time,' one journalist observed, that the 'real wrath of God is to leave us just where we are, not quite the shipwreck Winthrop feared, but a people adrift, with neither covenant, nor meekness, nor humility nor generosity to each other.' In the context of the 'Age of Trump', the sacred city is accorded an even stronger condemnatory role for an age in which the 'emphasis is on theatrics, deal making, and deal breaking, while "meekness", "gentleness", "patience", and "liberality", invite withering scorn and condescension.' It has functioned as a call-to-arms for America's twenty-first century religious leaders to 'remind the candidates for political office of the high moral ideals at America's beginning,' and help locate these in the nation once more (Geoghegan 2013; Rosenhagen 2016; Washington Post 20 February 2018; Dallas News 13 July 2018; Grandin 2016).

Yet in reaching back through time to Winthrop's seventeenth-century lay sermon, contemporary commentators inadvertently highlight the essentially static nature of the symbolism they deploy. They reveal the extent to which their nation has taken to heart Daniel Webster's injunction to locate the present in the past, to align the modern nation with the world created by the Founding Fathers, 'to belong' in a very real sense 'to their age' (Webster [1820] 1821, p. 6). The American state too-whose very future was in some jeopardy in the year that Webster spoke, the year of the Missouri Compromise, 
the first but not the last political effort to achieve equilibrium and avoid conflict between North and South, free and slave states-has largely relied on that collapsing of time since its inception: partly in order to sustain temporal balance and mitigate the potentially unsettling effects of territorial and population expansion, partly, for much of its history, to reinforce racial distinctions, and partly to establish its national claims in an international context. The result, however, is that American nationalism remains petrified in its past, suspended in time, trapped in the moment of the nation's eighteenth-century conception and birth. And the City upon the Hill finds itself stranded in Biblical time, at the heart of a nation grounded not in covenant, but by conflict.

Acknowledgments: The author would like to thank the two anonymous readers for Genealogy, for their extremely valuable and insightful comments on an earlier version of this article and, above all, Professor Atsuko Ichijo for her original encouragement to explore American nationalism from a fresh angle.

Conflicts of Interest: The author declares no conflict of interest.

\section{References}

Abbot, Abiel. 1799. Traits of Resemblance in the People of the United States of America to Ancient Israel. Haverhill: Moore and Stebbins.

Adair, James. 1775. History of the American Indians; Particularly Those Nations Adjoining to the Mississippi, East and West Florida, Georgia, South and North Carolina, and Virginia. London: E. \& C. Dilly.

Adam, Barbara. 1995. Timewatch: The Social Analysis of Time. Cambridge: Polity Press.

Allen, Paula Gunn. 1992. The Sacred Hoop: Recovering the Feminine in American Indian Traditions. Boston: The Beacon Press. Allen, Thomas M. 2008. A Republic in Time: Temporality and Social Imagination in Nineteenth-Century America. Chapel Hill: The University of North Carolina Press.

Anderson, Benedict. 1991. Imagined Communities: Reflections on the Origin and Spread of Nationalism, Revised Edition. London and New York: Verso.

Ayers, Edward L., and Bradley C. Mittendorf, eds. 1997. The Oxford Book of the American South: Testimony, Memory, and Fiction. New York and Oxford: Oxford University Press.

Bancroft, George. 1834. A History of the United States from the Discovery of the American Continent to the Present Time. Boston: Charles Bowen.

Bancroft, Charles. 1881. The Footprints of Time: And a Complete Analysis of the American System of Government. Burlington: R.T. Root Publisher.

Baritz, Loren. 1980. City on a Hill: A History of Ideas and Myths in America. Westport: Greenwood Press. First published 1964.

Barlow, Joel. 1787. An Oration, Delivered at the North Church in Hartford, at the Meeting of the Connecticut Society of the Cincinnati, July 4th 1787, in Commemoration of the Independence of the United States. Hartford: Hudson and Goodwin.

Beecher, Lyman. 1835. Plea for the West. New York: Leavitt, Lord and Company.

Bercovitch, Sacvan. 1978. The American Jeremiad. Madison: University of Wisconsin Press.

Bevir, Mark. 2008. What is Genealogy? Journal of the Philosophy of History 2: 263-75. [CrossRef]

Bíró-Nagy, Katalin. 2009. Reconceptualized Time and Space in Contemporary Native American Discovery Narratives. Americana 2. Available online: http://americanaejournal.hu/vol5no2/biro-nagy (accessed on 12 August 2018).

Boyer, Paul. 1992. When Time Shall Be No More: Prophecy Belief in Modern American Culture. Cambridge: Harvard University Press.

Bradford, William. 1953. Of Plymouth Plantation. Edited by Samuel Eliot Morison. New York: Knopf.

Brainerd, Cephas, and Eveline Warner Brainerd. 1901. The New England Society Orations. New York: The Century Company, vol. II.

Brooks, John. 1787. An Oration, Delivered to the Society of the Cincinnati in the Commonwealth of Massachusetts, July 4th. Boston: Edmund Freeman.

Callahan, William A. 2006. War, Shame, and Time: Pastoral Governance and National Identity in England and America. International Studies Quarterly 50: 395-419. [CrossRef]

Carter, Paul. 1988. The Road to Botany Bay: An Exploration of Landscape and History. New York: Alfred A. Knopf. First published 1987. 
Chamberlain, Joshua Lawrence. 1994. The Passing of the Armies: The Last Campaign of the Armies. Gettysburg: Stan Clark Military Books. First published 1915.

Coffey, John. 2013. Exodus and Liberation: Deliverance Politics from John Calvin to Martin Luther King, Jr. New York: Oxford University Press.

Connor, Walker. 1978. A Nation Is a Nation. Ethnic and Racial Studies 1: 379-88.

Connor, Walker. 2004. The Timelessness of Nations. Nations and Nationalism 10: 35-47. [CrossRef]

DavIs, DavID BrIon. 2007. Exiles, Exodus, and Promised Lands. The Tanner Lectures on Human Values 27: 121-64.

Davison, Graeme. 1993. The Unforgiving Minute: How Australians Learned to Tell the Time. New York: Oxford University Press.

Douglass, Frederick. 1999a. The Destiny of Colored Americans. In Frederick Douglass: Selected Speeches and Writings. Edited by Philip S. Foner. Chicago: Lawrence Hill, pp. 148-50.

Douglass, Frederick. 1999b. What to the Slave is the Fourth of July? In Frederick Douglass: Selected Speeches and Writings. Edited by Philip S. Foner. Chicago: Lawrence Hill, pp. 188-206.

Dudziak, Mary L. 2012. War Time: An Idea, Its History, Its Consequences. New York: Oxford University Press.

Eliade, Mircea. 1959. Cosmos and History: The Myth of the Eternal Return. Edited by Willard R. Trask. New York: Harper Torchbooks. First published 1954.

Eliot, Thomas Stearns. 1936. Collected Poems of T. S. Eliot 1909-1935. San Diego: Harcourt, Brace \& Co.

Evans, Vyvyan. 2013. Language and Time: A Cognitive Linguistics Approach. Cambridge: Cambridge University Press.

Everett, Edward. 1855. Dorchester in 1630, 1776, and 1855: Oration Delivered on the Fourth of July. Boston: David Clapp.

Faulkner, William. 1996. Intruder in the Dust. New York: Vintage. First published 1948.

Faulkner, William, and George Marion O’Donnell. 1990. Absalom, Absalom! New York: Random House. First published 1936.

Flaherty, Michael G. 1999. A Watched Pot: How We Experience Time. New York: New York University Press.

Foucault, Michel. 2003. Society Must Be Defended: Lectures at the College de France, 1975-76. Edited by Mauro Bertani and Alessandro Fontana. New York: Picador.

Foucault, Michel, and Jay Miskowiec. 1986. Of Other Spaces. Diacritics 16: 22-27. [CrossRef]

Fredrickson, George M. 1998. The Coming of the Lord: The Northern Protestant Clergy and the Civil War Crisis. In Religion and the American Civil War. Edited by Randall M. Miller, Harry Stout and Charles Wilson. New York: Oxford University Press, pp. 110-30.

Friend, Nathan. 2018. Inventing Revivalist Millennialism: Edwards and the Scottish Connection. Journal of Religious History 42: 52-71. [CrossRef]

Gaer, Joseph, and Ben Siegel. 1964. The Puritan Heritage: America's Roots in the Bible. New York: New American Library. Geoghegan, Tom. 2013. Our First and Scariest Inaugural Address, Courtesy of the Puritans. The Atlantic, January 20.

Gibbons, James, and Cardinal. 1892. Patriotism and Its Politics. The North American Review 154: 385-401.

Gillis, John R. 1997. A World of Their Own Making: Myth, Ritual, and the Quest for Family Values. Cambridge: Harvard University Press.

Givens, Douglas R. 2007. An Analysis of Navajo Temporality. Lanham: University Press of America.

Gorski, Philip. 2017. American Covenant: A History of Civil Religion from the Puritans to the Present. Princeton: Princeton University Press.

Grandin, Greg. 2016. There's Nothing Un-American about Donald Trump. The Nation, July 22.

Grant, Susan-Mary. 2000. North over South: Northern Nationalism and American Identity in the Antebellum Era. Lawrence: University Press of Kansas.

Grant, Susan-Mary. 2004. Southern Writers and the Civil War. In A Companion to the Literature and Culture of the American South. Edited by Richard Gray and Owen Robinson. Oxford: Blackwell Publishing, pp. 93-109.

Grant, Susan-Mary. 2005. When was the first new nation? Locating America in a national context. In When is the Nation: Towards an Understanding of Theories of Nationalism. Edited by Atsuko Ichijo and Gordana Uzelac. London: Routledge, pp. 157-76.

Grant, Susan-Mary. 2018. Promised land, chosen people: The landscapes and ligaments of American nationalism. Nations and Nationalism 24: 300-11. [CrossRef]

Green, Steven K. 2015. Inventing a Christian America: The Myth of the Religious Founding. New York: Oxford University Press.

Grosby, Steven. 2018a. Nationalism. In The Sage Handbook of Political Sociology. Edited by William Outhwaite and Stephen Turner. London: Sage Publications, pp. 587-603. 
Grosby, Steven. 2018b. Time, Kinship, and the Nation. Genealogy 2: 17. [CrossRef]

Guelzo, Allen C. 1999. Abraham Lincoln: Redeemer President. Grand Rapids: William B. Eerdmans Publishing Company. Hobsbawm, Eric, and Terence Ranger. 2003. The Invention of Tradition. Cambridge: Cambridge University Press. First published in 1983.

Hunt, Lynn. 2008. Measuring Time, Making History. Budapest: Central European University Press.

Hutchinson, John. 2017. Nationalism and War. Oxford: Oxford University Press.

Hutchinson, John. 2018. Bringing the study of warfare into theories of nationalism. Nations and Nationalism 24: 6-21. [CrossRef]

Kammen, Michael. 1997. In the Past Lane: Historical Perspectives on American Culture. New York: Oxford University Press.

Kohn, Hans. 1945. The Idea of Nationalism: A Study in its Origins and Background. New York: The Macmillan Company. First published 1944.

Kohn, Hans. 1961. American Nationalism: An Interpretative Essay. New York: The Macmillan Company. First published 1957.

Kraus, Michael. 1934. George Bancroft 1834-1934. The New England Quarterly 7: 662-86. [CrossRef]

Krichauff, Skye. 2017. Memory, Place and Aboriginal-Settler History: Understanding Australians' Consciousness of the Colonial Past. London: Anthem Press.

Lange, Carsten Hjort. 2017. Stasis and Bellum Civile: A Difference in Scale? Critical Analysis of Law 4: 129-40.

Leff, Michael. 1988. Dimensions of temporality in Lincoln's second inaugural. Communication Reports 1: 26-31. [CrossRef]

Lincoln, Abraham. 1838. Address before the Young Men's Lyceum of Springfield, Illinois, January 27. In The Collected Works of Abraham Lincoln. Edited by Roy P. Basler. New Brunswick: Rutgers University Press, pp. 108-15.

Lincoln, Abraham. 1858. Speech at Chicago, July 10. In The Collected Works of Abraham Lincoln. Edited by Roy Basler. New Brunswick: Rutgers University Press, pp. 484-502.

Lincoln, Abraham. 1861a. First Inaugural Address, March 4. In The Collected Works of Abraham Lincoln. Edited by Roy Basler. New Brunswick: Rutgers University Press, pp. 262-71.

Lincoln, Abraham. 1861b. Message to Congress in Special Session, July 4. In The Collected Works of Abraham Lincoln. Edited by Roy Basler. New Brunswick: Rutgers University Press, pp. 421-41.

Lincoln, Abraham. 1861c. Annual Message to Congress, December 3. In The Collected Works of Abraham Lincoln. Edited by Roy Basler. New Brunswick: Rutgers University Press, pp. 35-53.

Lincoln, Abraham. 1862. Annual Message to Congress, December 1. In The Collected Works of Abraham Lincoln. Edited by Roy Basler. New Brunswick: Rutgers University Press, pp. 518-37.

Lincoln, Abraham. 1863. Address Delivered at the Dedication of the Cemetery at Gettysburg, November 19. In The Collected Works of Abraham Lincoln. Edited by Roy Basler. New Brunswick: Rutgers University Press, p. 23.

Lincoln, Abraham. 1864a. Proclamation of a Day of Prayer. In The Collected Works of Abraham Lincoln. Edited by Roy Basler. New Brunswick: Rutgers University Press, pp. 431-32.

Lincoln, Abraham. 1864b. Proclamation of Thanksgiving. In The Collected Works of Abraham Lincoln. Edited by Roy Basler. New Brunswick: Rutgers University Press, pp. 55-56.

Lincoln, Abraham. 1865. Second Inaugural Address, March 4. In The Collected Works of Abraham Lincoln. Edited by Roy Basler. New Brunswick: Rutgers University Press, pp. 332-3.

Lintott, Andrew. 2015. Violence, Civil Strife and Revolution in the Classical City, 750-330 BC. London: Routledge.

Lipset, Seymour Martin. 1979. The First New Nation: The United States in Historical and Comparative Perspective. London: W.W. Norton \& Company.

Mann, Thomas. 1990. Lotte in Weimar: The Beloved Returns. Oakland: University of California Press.

McPherson, James M. 1991. Abraham Lincoln and the Second American Revolution. New York: Oxford University Press.

McPherson, James M. 1994. What They Fought For, 1861-1865. Baton Rouge, Louisiana and London: Louisiana State University Press.

Melville, Herman, and Robert Stanley Forsythe. 1852. Pierre: Or, the Ambiguities. New York: Harper and Brothers. Miller, Perry. 1953. Melville and Transcendentalism. Virginia Quarterly Review 29: 556.

Mitchell, Silas Weir. 1895. In War Time. New York: The Century Company. First published 1884.

Mitchell, Reid. 1989. Civil War Soldiers: Their Expectations and Their Experiences. New York: Touchstone Books. First published 1988. 
Montaigne, Michel de. 2004. On the Lame. In The Essays: A Selection. Edited by Michael A. Screech. London: Penguin Books, pp. 351-63.

Moorhead, James H. 1984a. The Erosion of Postmillennialism in American Religious Thought, 1865-1925. Church History 53: 61-77. [CrossRef]

Moorhead, James H. 1984b. Between Progress and Apocalypse: A Reassessment of Millennialism in American Religious Thought, 1800-1880. The Journal of American History 71: 524-42. [CrossRef]

Morgan, Patrick. 1988. Realism and Documentary: Lowering One's Sights. In The Penguin New Literary History of Australia. Edited by Laurie Hergenhan. Ringwood: Penguin, pp. 238-52.

Motley, John Lothrop. 1869. Historic Progress and American Democracy. New York: Charles Scribner and Company.

Neuman, Meredith Marie. 2013. Jeremiah's Scribes: Creating Sermon Literature in Puritan New England. Philadelphia: University of Pennsylvania Press.

Noble, David W. 1968. The Eternal Adam and the New World Garden. New York: George Braziller.

Orwin, Clifford. 1988. Stasis and Plague: Thucydides on the Dissolution of Society. The Journal of Politics 50: 831-47. [CrossRef]

Pease, Donald E. 1993. New Perspectives on U.S. Culture and Imperialism. In Cultures of United States Imperialism. Edited by Amy Kaplan and Donald E. Pease. Durham and London: Duke University Press, pp. 22-37.

Pease, Donald E. 2009. The New American Exceptionalism. Minneapolis: University of Minnesota Press.

Quandt, Jean B. 1973. Religion and Social Thought: The Secularization of Postmillennialism. American Quarterly 25: 390-409. [CrossRef]

Rable, George C. 2010. God's Almost Chosen Peoples: A Religious History of the American Civil War. Chapel Hill: The University of North Carolina Press.

Ravindran, Tathagatan, and Charles R. Hale. 2017. Rethinking the Left in the Wake of the Global "Trumpian" Backlash. Development and Change 48: 834-44. [CrossRef]

Ravitch, Diane. 1990. The American Reader: Words that Moved a Nation. New York: Harper Collins.

Reagan, Ronald. 1989. Farewell Address to the Nation. Available online: http:/ / www.presidency.ucsb.edu/ws/ ?pid=29650 (accessed on 12 August 2018).

Rodgers, Daniel T. 2012. Age of Fracture. Cambridge: Harvard University Press.

Roosevelt, Franklin D. 1941. Annual Message to Congress. Available online: https:/ fdrlibrary.org/documents / 356632/390886/readingcopy.pdf/42234a77-8127-4015-95af-bcf831db311d (accessed on 18 July 2018).

Rose, Deborah Bird. 2004. Reports from a Wild Country: Ethics of Decolonisation. Kensington: University of New South Wales Press.

Rosenhagen, Ulrich. 2016. The City upon the Hill in an Age of Donald Trump. HuffPost Blog. Available online: https:/ / www.huffingtonpost.com/ulrich-rosenhagen/the-city-upon-the-hill-in_b_12760342.html (accessed on 12 August 2018).

Saar, Martin. 2008. Understanding Genealogy: History, Power, and the Self. Journal of the Philosophy of History 2 : 295-314. [CrossRef]

Said, Edward W. 2001. Reflections on Exile and Other Literary and Cultural Essays. London: Granta Books, pp. $173-86$. First published 2000.

Schor, Paul. 2017. Counting Americans: How the US Census Classified the Nation. Edited by Lys Ann Weiss. New York: Oxford University Press.

Shaler, Nathaniel S. 1890. The Peculiarities of the South. The North American Review 151: 477-89.

Shapiro, Michael J. 2004. Methods and Nations: Cultural Governance and the Indigenous Subject. New York: Routledge. Smith, Anthony D. 2003. Chosen Peoples: Sacred Sources of National Identity. Oxford: Oxford University Press.

Smith, Anthony D. 2005. The genealogy of nations: An ethno-symbolic approach. In When Is the Nation? Towards an Understanding of Theories of Nationalism. Edited by Ichijo Atsuko and Uzelac Gordana. London: Routledge, pp. 94-112.

Stout, Harry S. 1986. The New England Soul: Preaching and Religious Culture in Colonial New England. New York: Oxford University Press.

Tackach, James. 2002. Lincoln's Moral Vision: The Second Inaugural Address. Jackson: University Press of Mississippi. Taylor, William R. 1979. Cavalier and Yankee: The Old South and American National Character. Cambridge and London: Harvard University Press. First published 1957.

Thorson, James Llewellyn. 1961. Chronometricals and Horologicals: The Key to a Basic Theme in the Fiction of Herman Melville. Master's thesis, University of Nebraska, Lincoln, NE, USA. 
Tuveson, Ernest Lee. 1968. Redeemer Nation. Chicago: University of Chicago Press.

Twain, Mark. 1996. Life on the Mississippi. New York: Signet Classics. First published 1883.

Waldstreicher, David. 1997. In the Midst of Perpetual Fetes: The Making of American Nationalism, 1776-1820. Chapel Hill and London: University of North Carolina Press.

Washington, George. 1796. Farewell Address. Available online: http://avalon.law.yale.edu/18th_century/ washing.asp (accessed on 17 July 2018).

Webster, Daniel. 1821. Discourse Delivered at Plymouth, December 22, 1820, in Commemoration of the First Settlement of New-England. Bost: Wells and Lilly. First published 1820.

Wells, Cheryl A. 2005. Civil War Time: Temporality and Identity in America, 1861-1865. Athens: University of Georgia Press.

White, Ronald C. 2002. Lincoln's Greatest Speech: The Second Inaugural. New York: Simon and Schuster.

Wilson, Major L. 1974. Space, Time, and Freedom: The Quest for Nationality and the Irrepressible Conflict, 1815-1861. Westport: Greenwood Press.

Winslow, Edward. 1865. Mourt's Relation. Reprint. Boston: George C. Rand and Avery. First published 1622.

Winthrop, John. 1630. A Modell of Christian Charity. Available online: https://history.hanover.edu/texts/ winthmod.html (accessed on 8 August 2018).

Winthrop, Charles R. 1876. Oration on the Centennial of the Declaration of Independence, Boston 4 July. Boston: J. Wilson and Son.

Wolfe, Thomas. 1999. The Web and the Rock. Baton Rouge: Louisiana State University Press. First published 1937. Yablon, Nick. 2012. "Land of Unfinished Monuments": The Ruins-in-Reverse of Nineteenth-Century America. American Nineteenth Century History 13: 153-97. [CrossRef]

(c) 2018 by the author. Licensee MDPI, Basel, Switzerland. This article is an open access article distributed under the terms and conditions of the Creative Commons Attribution (CC BY) license (http:/ / creativecommons.org/licenses/by/4.0/). 